\title{
Chris Stevens Joins AMS Executive Staff
}

\author{
Allyn Jackson
}

In August 2014, the AMS had the great pleasure of welcoming T. Christine Stevens as a member of the executive staff. Universally known as Chris, she embodies a rare combination of experience and personal qualities that make her ideally suited to her new post. The AMS is also fortunate to retain the experience and skill of Chris's predecessor, Ellen Maycock, who has shifted to part-time status, in advance of her retirement, and who will work on specific projects.

"The AMS is delighted to have Chris Stevens joining the staff," said AMS Executive Director Donald McClure. "She is an outstanding member of the mathematical community whose achievements have been recognized by the whole community and by many awards. She brings tremendous experience, insight, and expertise to the position, and her energy and enthusiasm are infectious. She will be a great asset to the Society."

Chris is the AMS associate executive director for Meetings and Professional Services, which, as she put it, is "such a long title that it conveys no information at all." This remark exhibits her characteristic subversive humor; almost any conversation with Chris is bound to be laced with laughter. Her light-hearted side coexists easily with her gravitas: Profoundly committed to mathematics and the mathematical community, Chris possesses keen insights into all aspects of the mathematics profession.

Chris is no doubt best known for her leadership of Project NExT, a longstanding and highly successful program sponsored by the Mathematical Association of America (MAA). In the spring of 1993, while Chris was a visiting mathematician at the MAA, James R. C. Leitzel brought up the

Allyn Jackson is senior writer and deputy editor of the Notices. Her email address is axj@ams . org.

DOI: http://dx.doi.org/10.1090/noti1201 idea of a conference for new PhDs who were interested in teaching issues. This was the starting point for Project NExT. The name, an acronym for "New Experiences in Teaching", evokes the idea of preparing the "next generation" of mathematics faculty. Chris directed Project NExT jointly with Leitzel from 1994 until his death in 1998. Chris then served as director from 1998 until 2009.

"What Project NExT does is to welcome new

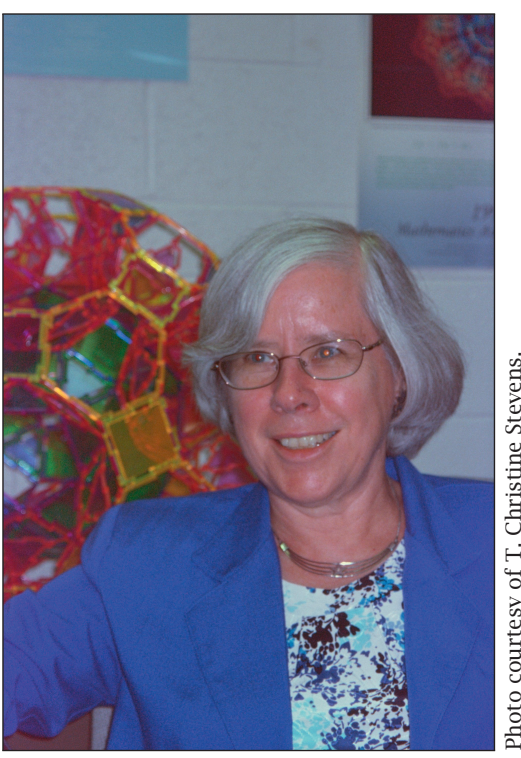

T. Christine Stevens PhDs into the mathematical community," Chris explained. The program helps young mathematicians successfully make the transition from graduate student to full-time faculty member. While attention is paid to research and scholarship, the main focus of Project NExT is excellence in teaching. One of its key features is a national network of peers, through which Project NExT Fellows can discuss the challenges they face, share ideas, and support each other. "They are all going through the same things: trying to teach a course they've never taught before-or trying to teach a course they've never even taken!" Chris said. "Part of what makes Project NExT work is this vibrant network." Some Fellows stay in touch over many years; indeed, there is still activity in the peer network of the initial Project NExT group of twenty years ago.

Several societies sponsor Project NExT Fellows; the AMS has been supporting six Fellows every year 
since 2001. To date, Project NExT has reached a total of 1,560 young mathematicians. Many of them have become national leaders and have helped to energize mathematical life and teaching across the country. Project NExT has also had an impact by serving as an existence proof of the great benefits of careful mentoring and support of young people entering the profession. For example, the success of Project NExT was surely an encouragement to the AMS when it launched the Mathematics Research Communities (MRC) program. Each year MRC hosts a set of research conferences aimed at young mathematicians, with the goal of helping them to build collaborations to sustain their research as they move through their careers. (Although MRC is in Chris' division at AMS, Ellen Maycock will continue to oversee the program.)

In 2004, Chris received the MAA's highest award for service, the Gung and Hu Award for Distinguished Service to Mathematics, primarily for her work on Project NExT. Her outstanding teaching has been recognized by the MAA's Haimo Award for Distinguished College and University Teaching (1997). An alumna of Smith College, she was awarded the Smith College Medal in 2010. She was among the inaugural class of AMS Fellows named in 2012. In October 2014, the Association for Women in Mathematics announced that Chris would receive the 2015 Louise Hay Award for Contributions to Mathematics Education.

Chris earned her $\mathrm{PhD}$ in 1978 from Harvard University, under the direction of Andrew Gleason. After faculty positions at Mount Holyoke College and Arkansas State University, she settled at Saint Louis University, where she worked for twenty-five years, five of them as chair of the Mathematics and Computer Science Department. Chris's interest in policy and administrative matters led her to serve as the AMS/MAA/SIAM Congressional Science Fellow (1984-1985). In addition, she was a rotator at the National Science Foundation, serving during 1987-89 as a program director in the Teacher Enhancement Program. She has served extensively in professional organizations, for example on the AMS Council (2011-2014) and the AMS Committee on Science Policy (2011-2014). Currently, she chairs the MAA's Council on Prizes and Awards and is a member of the MAA Board of Governors.

In the past couple of years, Chris has been involved in the response of the mathematical community to Engage to Excel, a 2012 report of the President's Council of Advisors on Science and Technology (PCAST). The report caused controversy by suggesting, among other things, that college mathematics courses would be better taught by nonmathematics faculty. Chris was one of eight leaders in the mathematical community who signed a statement about the PCAST report that appeared in the October 2012 issue of the Notices. "The PCAST report made many useful points, but it was also a real wake-up call for the mathematical community," Chris said. "Many scientists are unaware of all the good work that we have been doing to improve undergraduate mathematics education. We need to showcase our achievements in providing effective teaching, and we need to share our experience that there is no single approach that will work for all students and all instructors at all institutions. On the other hand, there are some serious issues in mathematics instruction that must be addressed, if we are going to reach the goals set forth in the PCAST report, and they will require resources and hard work."

Chris's interest in education, policy, and administration has been the main focus of her career, but it has not eclipsed her research. A noted scholar in topological groups, she supervised two $\mathrm{PhD}$ theses, and her most recent research paper was published this year. Also this year, she spent five months at the Universidad Complutense de Madrid as a Fulbright Senior Researcher. The demands of her AMS position probably mean she will now have less time for research, but she hopes to keep at it."I'm not going cold turkey on research," she said.

The fit between the needs of the AMS and Chris's experience and interests is just about perfect. In describing what she will be doing at the AMS, Chris noted the various ways mathematicians interact with the Society. One of the main ones is through "print and pixels"-that is, through books, journals, and online services like MathSciNet. Other ways mathematicians interact with the AMS come under the heading of "activities and programs": meetings, travel grants, fellowships such as the Centennial Research Fellowships, and so on. These are the kinds of things Chris will oversee.

"One of the roles of professional organizations is to do things that mathematicians can't do individually but can do collectively, like publishing books or holding meetings," she said. "A second role is to be the public face of mathematics and to articulate to the government and to society at large the importance, significance, and beauty of mathematics and the importance of mathematics education. I see the AMS as one of a group of mathematical professional organizations that contributes to these activities, and I'm looking forward to playing a role in its efforts." 